\title{
KLAIPE்DOS IR KITŲ BALTIJOS UOSTAMIESČIŲ URBANISTINĖS STRUKTŪROS KAITA GLOBALIZACIJOS KONTEKSTE
}

\author{
Eglè Truskauskienė \\ Urbanistikos katedra, Vilniaus Gedimino technikos universitetas, \\ Pylimo g. 26/Trakug. 1, LT-01132 Vilnius, Lietuva \\ El.paštasetruske@gmail.com \\ Iteikta 20090309
}

\begin{abstract}
Santrauka. Straipsnyje pateikiama platesnio disertacinio darbo „Lietuvos pajūrio urbanistinė dinamika“ dalis. Ši dalis skirta Klaipèdos urbanistinès raidos problemoms nagrinèti ir naujoms galimybèms ịvertinti, veikiant globalizacijos faktoriams. Klaipėda lyginama su kitais Baltijos uostamiesčiais, tiriant jų plètros potencialą ir urbanistinės struktūros dinamiką. Tyrime ryškẻja svarbiausia globalizacijos epochos urbanistinès dinamikos tendencija - uosto ir miesto sisteminé plètra. Šių struktūrų bendras vystymas leidžia efektyviai spręsti tiek uosto, tiek miesto problemas. Tokiame kontekste Klaipėda išsiskiria kaip uostamiestis, kuris palei pakrantę juda atvirkščiai, nei diktuoja natūralus uostų raidos ciklas, nes kryptingą urbanistinę plètrą komplikuoja gamtiniai veiksniai, teritorijų stygius bei sunkiai suderinami įvairių ūkinių subjektų, turinčių interesų pakrantėse, poreikiai. Pritaikius kitų Baltijos uostų aktualią praktiką, nagrinëjant pakrančių efektyvumą, taikant naujus uostų plètros modelius ir sisteminio planavimo diktuojamas urbanistinės raidos kryptis, Klaipėdos uostamiestyje taip pat galima rasti racionalių plètros sprendimų. Klaipédai siūloma urbanistinès raidos kryptis - sisteminis uosto ir miesto planavimas, rūpinantis ryšiais tarp šių, kol kas menkai susijusių, uostamiesčio dalių.
\end{abstract}

Reikšminiai žodžiai: urbanistinė dinamika, globalizacija, sisteminè plètra, uosto raidos ciklas, plètra žaliuosiuose, ruduosiuose ir mèlynuosiuose plotuose, integracija.

\section{Ivadas}

Visuomenëje, moksle, politikoje, ekonomikoje, technologijose ir daugelyje kitų sričių nuo pat jų atsiradimo momento nuolatos vyksta pokyčiai, kurių aktyvumą lemia daug veiksnių, tačiau kaip svarbiausią ir ịtakingiausią savo mastu šiandien būtina išskirti globalëjimą. Tai procesas, kuris apibūdinamas kaip minètų sričiu visuotinè integracija. Globalizacija turi nemažai ittakos miestų urbanistinei raidai - čia labai didelè ekonominių, technologinių, sociokultūrinių ir politinių jègų koncentracija ir didelis gyventojų tankis. Pavyzdžiui, keturi iš penkių Europos piliečių gyvena miestuose, o jų gyvenimo kokybei tiesioginę itaką daro miesto aplinka. Uostamiesčiuose šis poveikis dar stipresnis, nes uostu plètra į ekonominius ir technologinius pokyčius reaguoja labai greitai bei aktyviai.

Panašų globalèjimo laikotarpi pasaulis jau išgyveno nuo XIX a. vidurio iki XX a. trečiojo dešimtmečio.
Tuomet ryšius tarp skirtingų pasaulio dalių suaktyvino pramonès revoliucija, geležinkeliai, nutiestas transatlantinis kabelis. Pirmoji globalëjimo epocha subyrèjo nuo vienas kitą lydejjusių Pirmojo pasaulinio karo, Rusijos revoliucijos ir Didžiosios depresijos smūgių krušos, kurie suskaldè pasauli ir fiziškai, ir ideologiškai (Friedman 2005). Akivaizdu, kad šis globalejimo laikotarpis buvo labai svarbus uostamiesčiams augti: sustiprejjo jų politinè ir ekonominè reikšmè, geležinkelių atsiradimas lèmé didžiulị technologinị lūžį ir labai padidejusias uostų teritorijas.

Oficialiai padalytą po Antrojo pasaulinio karo pasauli sustingdè šaltasis karas. Tai truko maždaug nuo 1945 m. iki 1989 m., kai, griuvus Berlyno sienai, ji pakeitè nauja globalèjimo epocha (Friedman 2005). Straipsnyje daugiausia dèmesio bus skiriama kaip tik šiai globalejjimo epochai bei jos jègoms, veikiančioms 
uostamiesčių urbanistinę dinamiką. Ji pasirinkta visu pirma todèl, kad šiandieninès globalizacijos mastas ir intensyvumas daug didesni nei ankstesnès, taigi svarbesnis ir stipresnis ekonominių bei technologinių procesų poveikis urbanistinių struktūrų raidai. Antra dabartiné globalizacija sieja ị visumą daug reiškinių bei arbitražuoja informaciją iš ịvairių perspektyvų. Šis požiūris paneigè funkcinio zonavimo principą, kuris buvo miestų krizès, prasidejjusios prieš 20-30 m., priežastimi ir leido atsirasti naujai, visuotinai pripažintai darniosios plètros planavimo koncepcijai (Juškevičius, Jauneikaitè 2008). Naujosios koncepcijos esminiai tikslai - funkcinè integracija, sisteminis planavimas ir gebëjimas valdyti urbanistinị vystymąsi - ypač aktualūs uostamiesčiams. Ankstesnè funkcinio zonavimo įtaka čia lèmè ne tik didžiules vienarūšes ir siaurai specializuotas teritorijas, bet ir pakrančių - svarbios urbanistinio identiteto dalies - atskyrimą nuo miesto. Darniosios plètros tikslai uostamiesčiuose skatina kiekybinę plettrą tapti kokybine, iš naujo įvertinti pakrančių naudojimo efektyvumą bei ieškoti teritorinių rezervų. Tai didžiulio uosto ir miesto teritorijų persiskirstymo priežastis.

\section{Objektas}

Straipsnio tyrimo objektas - Klaipedos uostamiestis. Jis tiriamas lyginamosios analizès principu, gretinant su kitais Baltijos uostamiesčiais. Tai nevienodo dydžio miestai, dažniausiai užimantys 100-200 kv. km (išskyrus Sankt Peterburgą ir Suomijos miestus, kurių teritorija dažniausiai skaičiuojama kartu su periferija) (1 lentelè). Vis dèlto toks dydžių skirtumas leidžia statyti uostamiesčius ị vieną gretą ir palyginti su Klaipėda, ypač nagrinejjant parametrus, kurie mažai susiję su paties miesto užimama teritorija: pakrančiu naudojimo efektyvumą bei miestų centrinių dalių ir uostų santykị (2 lentelè). Pastarasis palyginimas ypač aktualus, nes Baltijos uostamiesčius sieja panašūs urbanistinès raidos ypatumai - tai Europos tradicijos miestai. Jų branduoliai pradejjo formuotis prieš $4-5$ šimtus metų lygiagrečiai su uostu, todèl tankus urbanistinis audinys ypač stipriai konkuruoja su neturinčiomis kur plèstis uostų teritorijomis. Svarbu pažymèti, kad ši konkurencija vyko nevienodomis politinèmis, ekonominèmis ir socialinemis sąlygomis.

Palyginimas yra tikslingas ir todel, kad visi šie uostamiesčiai šiandien vienodai veikiami to paties proceso - globalizacijos. Dèl globalizacijos, $2004 \mathrm{~m}$. prie Europos Sąjungos prisijungus naujoms narèms, Baltija tapo vidine šios Sąjungos jūra, todèl daugelis Baltijos uostų dabar priklauso tai pačiai sistemai ir or- ganizacijoms (ESPO, BPO). Europos Sąjungos uostų politikoje jiems numatyti vienodi saugumo, transporto reguliavimo, aplinkosaugos, oro taršos, darnios plètros reikalavimai. Baltijos uostų organizacija, savo ruožtu, rūpinasi efektyvių transporto ryšių organizavimu. Dar vienas uostus vienijantis bruožas - didejjanti konkurencija, nes globalizacija labai sutrumpino kelią nuo naujovès iki proceso ir paskatino ekonominį bei technologini aktyvumą.

Dèl globalizacijos supanašèjus Baltijos uostamiesčių raidos sąlygoms, tiriami urbanistinès dinamikos skirtumai padeda ịvertinti nagrinejjamo objekto Klaipèdos - plètros privalumus bei trūkumus.

\section{Problema}

Vanduo - jūra, kanalas, upè ar ežeras - visuotinai svarbus resursas, kuris gretimoms teritorijoms savaime suteikia pridètinès vertès. Tai nekilnojamojo turto vystytojų principas. Kai kurie mokslininkai šią koncepciją pristato kaip esminị pakrančių renovavimo ir transformavimo aspektą, teigdami, jog dèl transporto inovacijų įtakos atsilaisvinę uosto plotai savaime gali prisiimti meninès aplinkos vaidmenị ir išstumti funkcinį zonavimą. Šios nuostatos šalininkai mano, jog pakrantès pačios inspiruoja ryšius tarp miesto ir aplinkos dèl specifinio resurso - vandens (Remesar 2005). Vis dèlto tokia nuostata nèra pakankama sąlyga efektyviam pakrančių naudojimui, užtikrinančiam funkcijų intensyvumą bei meninę-urbanistinę kokybę, nes:

1. Nesprendžia, kokiu būdu turètų būti identifikuojamos renovuotinos uostų teritorijos.

2. Nenumato tokių teritorijų sisteminès plètros ir ryšių su kitomis teritorijomis.

3. Neịpareigoja naujai kuriamais objektais spręsti viešųjų erdvių, visuomenès gerovès ir išliekamosios vertės klausimų („pakrantėse žmonès nuperka viską") (Carley et al. 2007). Taigi, vadovaujantis anksčiau paminèta koncepcija, menkai naudojamos uostų teritorijos taip ir lieka tiketinomis, o ne integruotomis - panašiai kaip funkcinio zonavimo principu suplanuoti teritoriniai rezervai.

Pažangiausiuose Baltijos uostamiesčiuose urbanistinè dinamika vyksta visiškai kita kryptimi:

1. Iš naujo verifikuojamas potencialas, kurị uostų teritorijos praranda arba igyja, keičiantis ekonominèms sąlygoms ir technologijoms.

2. Numatomos šių teritorijų vystymo programos, nagrinejjant naujus uosto ir miesto poreikius bei sisteminị ryši. 
1 lentelè. Baltijos uostų naudojamų pakrančių efektyvumas, vertinant $2007 \mathrm{~m}$. duomenis bei rezultatus

Table 1. Efficiency of waterfronts used by the Baltic seaports in 2007

\begin{tabular}{|c|c|c|c|c|c|c|c|}
\hline Miestas & $\begin{array}{l}\text { Gyventojų } \\
\text { skaičius }\end{array}$ & $\begin{array}{l}\text { Plotas } \\
\left(\mathrm{km}^{\sim}\right)\end{array}$ & $\begin{array}{l}\text { Uosto } \\
\text { plotas } \\
\text { (ha) }\end{array}$ & $\begin{array}{l}\begin{array}{c}\text { Krantinių } \\
\text { ilgis }\end{array} \\
\text { (km) }\end{array}$ & $\begin{array}{l}\text { Kroviniu } \\
\text { apyvarta } \\
\text { (mln.t) }\end{array}$ & $\begin{array}{c}\text { Krovinių } \\
\text { kiekis/ } \\
\text { uosto ha } \\
\text { (mln.t/ha) }\end{array}$ & $\begin{array}{c}\text { Krovinių } \\
\text { kiekis/ } \\
\text { krantinės km } \\
\text { (mln. t/km) }\end{array}$ \\
\hline Sankt Peterburgas (RU) & 4662547 & 606,00 & 891 & 18,70 & 59,609 & 0,07 & 3,19 \\
\hline Gioteborgas (S) & 478055 & 198,00 & 360 & 20,00 & 40,353 & 0,11 & 2,02 \\
\hline Talinas (E) & 392306 & 148,19 & 747 & 10,18 & 35,865 & 0,05 & 3,52 \\
\hline Ventspilis (LV) & 43806 & 55,40 & 2358 & 11,01 & 30,473 & 0,01 & 2,77 \\
\hline Klaipèda (LT) & 183828 & 87,40 & 498 & 26,7 & 27,362 & 0,05 & 1,02 \\
\hline Ryga (LV) & 735241 & 307,00 & 1962 & 13,82 & 25,216 & 0,01 & 1,82 \\
\hline Liubekas (DE) & 211874 & 214,00 & 169 & 5,55 & 22,175 & 0,13 & 3,99 \\
\hline Gdanskas (PL) & 459072 & 262,03 & 653 & 21,20 & 19,944 & 0,03 & 0,94 \\
\hline Rostokas (DE) & 198993 & 180,99 & 750 & 26,50 & 19,585 & 0,03 & 0,74 \\
\hline Kopenhaga (DK)/ & 501664 & 89,11 & 202 & 16,50 & $7,379+$ & 0,09 & 1,10 \\
\hline Malmè (S) & 267171 & 72,00 & & & $\begin{array}{r}10,672= \\
18,051\end{array}$ & & \\
\hline Kaliningradas (RU) & 430003 & 215,70 & 230 & 6,37 & 15,625 & 0,07 & 2,45 \\
\hline Ščecinas (PL)/ & 41190 & 300,83 & $11,47+$ & $7,70+$ & $8,008+$ & 0,27 & 1,60 \\
\hline Svinouiscis (PL) & 40899 & 197,23 & $\begin{array}{r}47,00= \\
56,47\end{array}$ & $\begin{array}{r}1,90= \\
9,60\end{array}$ & $\begin{array}{r}7,385= \\
15,393\end{array}$ & & \\
\hline Frederisija (DK) & 49463 & 134,46 & 75 & 4,00 & 15,326 & 0,20 & 3,83 \\
\hline Gdynè (PL) & 252443 & 135,49 & 492 & 17,70 & 14,849 & 0,03 & 0,84 \\
\hline Helsinkis (FI) & 559716 & 186,07 & 211 & 8,54 & 13,443 & 0,06 & 1,57 \\
\hline Orhusas (DK) & 293510 & 91,00 & 227 & 13,50 & 12,189 & 0,05 & 0,90 \\
\hline Kotka (FI) & 54705 & 271,30 & 460 & 4,01 & 10,606 & 0,02 & 2,64 \\
\hline Nantalis (FI) & 14291 & 283,48 & 24 & 1,28 & 8,510 & 0,35 & 6,65 \\
\hline Helsingborgas (SE) & 93838 & 37,63 & 148 & 4,10 & 7,665 & 0,05 & 1,87 \\
\hline Karlshamnas (DK) & 18768 & 13,44 & 75 & 3,00 & 7,328 & 0,10 & 2,44 \\
\hline Rauma (FI) & 36489 & 495,51 & 108 & 3,23 & 6,860 & 0,06 & 2,12 \\
\hline Hamina (FI) & 21576 & 609,5 & 315 & 2,98 & 5,877 & 0,02 & 1,97 \\
\hline Poris (FI) & 76426 & 517,14 & 62 & 2,70 & 5,648 & 0,09 & 2,09 \\
\hline Kokola (FI) & 37266 & 1444,17 & 160 & 1,97 & 4,791 & 0,03 & 2,43 \\
\hline Jevlè (DK) & 68700 & 41,79 & 30 & 2,00 & 4,649 & 0,15 & 2,32 \\
\hline Stokholmas (S) & 761721 & 178,00 & 60 & 8,37 & 4,599 & 0,08 & 0,55 \\
\hline
\end{tabular}


3. Teritorijų vystytojai įpareigojami spręsti meninèsurbanistinès kokybès klausimus, numatant teritorijose funkcijų įvairovę, viešąsias erdves bei keliant aukštus reikalavimus architektūrinei kokybei.

Klaipedos uostamiesčio pakrančiu vystymas yra savaiminis ir atsitiktinis, nes neplanuojamas kaip bendra uosto ir miesto urbanistinè sistema. Taip yra todèl, kad valdymo modelyje dalyvauja trys skirtingi subjektai: Klaipèdos valstybinis jūrų uostas, valdantis didžiąją pakrantès dalị ir turintis plètros interesų miesto teritorijoje; privačios įmonès, turinčios interesų pigiai nuomotis uosto žemę; savivaldybè, turinti priejjimo prie vandens, kuris galètų padidinti miesto teritorijų vertę, interesą. Toks sisteminio planavimo nebuvimas skatina šias problemas:

1. Neorganizuojami efektyvaus pakrančių naudojimo būdai, toliau programuojamas funkcinis zonavimas ir rezervinių teritorijų plètra.

2. Uosto ir miesto teritorijos neplanuojamos atsižvelgiant $\mathfrak{i}$ vienos bei kitos pusés interesus ir nenumatomas jų tarpusavio integralumas.

3. Miesto ir uosto planuotojai suinteresuoti tik kiekybine, bet ne kokybine plètra.

\section{Tikslas}

Šio straipsnio tikslas - palyginti Klaipèdos ir kitų Baltijos uostamiesčių, panašių savo dydžiu bei raidos problemomis, urbanistinę dinamiką globalizacijos kontekste; išskirti dominuojančias plètros tendencijas; išnagrinèti perspektyviausias vystymo kryptis ir jų taikymo Lietuvos uostamiesčiui galimybes. Siekiant užsibrežto tikslo, bus nagrinėjamos Baltijos uostamiesčių urbanistinès dinamikos priežastys, rezultatai bei mastai esant skirtingam technologijų įsisavinimo aktyvumui, skirtingoms socialinèms, ekonominems aplinkybėms. Analizuojant Baltijos uostamiesčių urbanistinę dinamiką, straipsnyje bus sprendžiami šie uždaviniai:

1. Nagrinëjamas Baltijos uostų teritorijų ir pakrančių naudojimo efektyvumas.

2. Tiriama uostamiesčiu kaita, naudojant uostų gyvavimo ciklo modeli.

3. Tertinami uostamiesčių urbanistinio vystymo mastai bei jų priklausomybè nuo uosto valdymo modelio.

4. Išskiriamos dominuojančios Baltijos uostų plètros tendencijos.

5. Nagrinejjamos perspektyviausios uostų vystymo kryptys ir šių krypčių taikymo Klaipèdoje galimybès.

\section{Baltijos uostamiesčių kaitos veiksniai}

Kaip jau minèta, esminè Baltijos uostamiesčių kaitos priežastis - globalizacija, apimanti daugybę vienas kitą lemiančių veiksnių. Svarbiausi iš jų:

1. Vidinis uostų poreikis keistis, kurị inspiruoja didèjanti ir skatinama tarpusavio konkurencija.

2. Išorinis miesto spaudimas aktyviai naudoti pakrančių teritorijas, susijęs su poreikiu turèti priëjimą prie vandens bei darniosios plettros tikslais.

Pirmoji veiksnių grupè - technologinè ir ekonominè uostų raida, suaktyvejjusi apie devintąji dešimtmetį. Auganti konkurencija paskatino jūrų transporto technologijų vystymąsi, ieškant greitesnių ir pigesnių krovos būdų, kurie lèmè staigų laivų gabaritų augimą. Kita vertus, uostams pasidarè svarbu prisiderinti prie technologinių pokyčių, laiku investuoti i plètrą bei didesnį našumą ir rasti greitą kelią nuo inovacijos prie jos taikymo (Uosto valdymas... 2005). Vidinis uostų poreikis keistis šiomis sąlygomis yra susijęs su naujų teritorijų būtinybe prie gilesnių vandenų bei su mažejančiomis galimybėmis efektyviai naudoti esamas teritorijas.

Antroji veiksnių grupé - miesto ir rinkos diktuojamos sąlygos, nes miestas neturi arba nenori aukoti teritorijų, kuriose būtų galima uosto plètra, o nekilnojamojo turto rinka verčia atsisakyti prastai naudojamų teritorijų, siūlydama aukštesnę kainą.

Abi kaitos veiksnių grupès apibrèžtos skirtingų interesų, tačiau Baltijos uostamiesčių kaitai duoda tą patị postūmị - skatina verifikuoti pakrančių potencialą, kurio įvertinimas uostui leistų su miestu derètis dèl naujų teritorijų, o miestui su uostu - dèl laisvesnio priejjimo prie vandens.

Pateiktoje 1 lentelëje pakrančiu efektyvumui ịvertinti taikomas lyginamosios analizès metodas. Su nagrinëjamu objektu - Klaipėda - lyginami visi Baltijos uostamiesčiai, vykdantys krovą ir turintys ne mažiau kaip 4,5 mln. tonų apimtị. Šiai uosto veiklai reikia didžiausių teritorijų, o uosto dalių integravimas ị miesto audinị kelia daugiausia problemų. Uostų eilès tvarka lenteleje numatyta būtent pagal kraunamų krovinių kiekį. Akivaizdu, kad Klaipedos uosto pakrančių ilgis yra pats didžiausias iš visų Baltijos uostų, nors pagal krovos darbus ji tik penkta. Tokị didelị ilgị būtų galima sieti su tuo, kad naudojamas gana siauras pakrantės ruožas. Vis dèlto Gioteborgas, net ir išsidèstęs trumpesneje pakrantès atkarpoje, uosto veiklai naudoja mažesni plotą. Nagrinejjant mažiau už Klaipédą perkraunančių uostų pakrančių efektyvumą, lyginami 
išvestiniai dydžiai - krovinių kiekis, tenkantis pakrantès plotui bei pakrantès ilgiui.

Dešimties iš nagrinėjamų dvidešimt šešių uostų abu rodikliai rodo daug didesnị pakrančių naudojimo intensyvumą nei Klaipèdos. Keturi uostai - Talino, Kotkos, Raumos ir Kokolos - turi mažesni uosto ploto naudojimo intensyvumą nei Klaipeda, tačiau jų pakrantès kilometrui tenka daugiau nei 2 kartus daugiau krovinių. Orhusas ir Hamina yra intensyviai vystomi uostai, kuriuose kol kas ne visos krantinès dirba visu pajègumu. Taigi, nagrinèjant Baltijos uostų pakrančių naudojimo intensyvumą, galima teigti, kad likusieji dešimt uostų, tarp jų ir Klaipèda, turi labai didelį plètros potencialą, kurị būtina panaudoti sisteminiam uosto ir miesto vystymui.

\section{Miesto ir uosto vystymo metodai}

Tiesioginị ryši tarp jūrų transporto raidos ir funkcijos išsidèstymo erdvejje iliustruoja profesoriaus J. H. Bird'o 1963 m. sukurtas ir iki šių dienų nepraradęs aktualumo modelis (1 pav.). Tai esminis atspirties taškas visiems uostus tiriantiems mokslininkams, nes padeda sistemiškai analizuoti uostamiesčiu urbanistinę dinamiką, tiksliai identifikuoti teritorijų raidos problemas ir rasti tinkamą vystymo metodą. J. H. Bird'o modelis yra nepaneigtas, nes beveik be išimčių tinka visiems uostams. Jis nuolatos plètojamas, bandant atsižvelgti i vèlesnius uostų raidos etapus ir ịtraukti daugiau nagrinèjamų aspektų.
Genezè pradedama nuo uosto įkūrimo vietos. Ši vieta priklausė nuo geografinių sąlygų ir buvo susijusi su labiausiai nuo jūros atitolusiu prekybinių laivų navigacijos tašku. Kitas etapas - uosto plètra. Ši etapą lèmè pramonès revoliucija. Prieplaukos išsiplètè, pradèti konstruoti vis ilgesni molai, skirti perkrauti vis daugiau krovinių ir aptarnauti keleivių, priimti didesnius laivus, juos remontuoti ir statyti naujus. I uosto terminalus buvo integruotos geležinkelio linijos, užtikrinančios susisiekimą su didžiulèmis sausumos teritorijomis. Tai lèmé dar didesnị jūrų transporto augimą. Ekspansija daugiausia vyko tolyn nuo miesto centro, gilesnių vandenų link. Vèliau èjusiame specializacijos etape buvo tokia uostų kaita: dar labiau išaugo laivų gabaritai, atsirado dar didesnis erdvès poreikis kroviniams valdyti ir sandèliuoti. Uosto veikla tapo koncentruota vietose, labai atitolusiose nuo seniausių ịrenginių. Tikrosios uostų vietos, dažniausiai išsidèsčiusios senamiesčio teritorijose, atgyveno ir buvo apleistos (Bird 1963).

Šiame modelyje nagrinejjami penki, turintys didžiausią plètros potencialą bei labiausiai išorinių ir vidinių kaitos faktorių veikiami uostamiesčiai: Stokholmo, Helsinkio, Gioteborgo, Rygos (2 ir 3 lentelès, dešinè pusè). Jie lyginami su nagrinejjamu objektu - Klaipèda.

Stokholme uosto teritorijos yra gerokai atsitraukusios nuo istorinio branduolio. Čia yra išlikusi tik siaura uosto užimama teritorija, visiškai integruota $\mathfrak{i}$

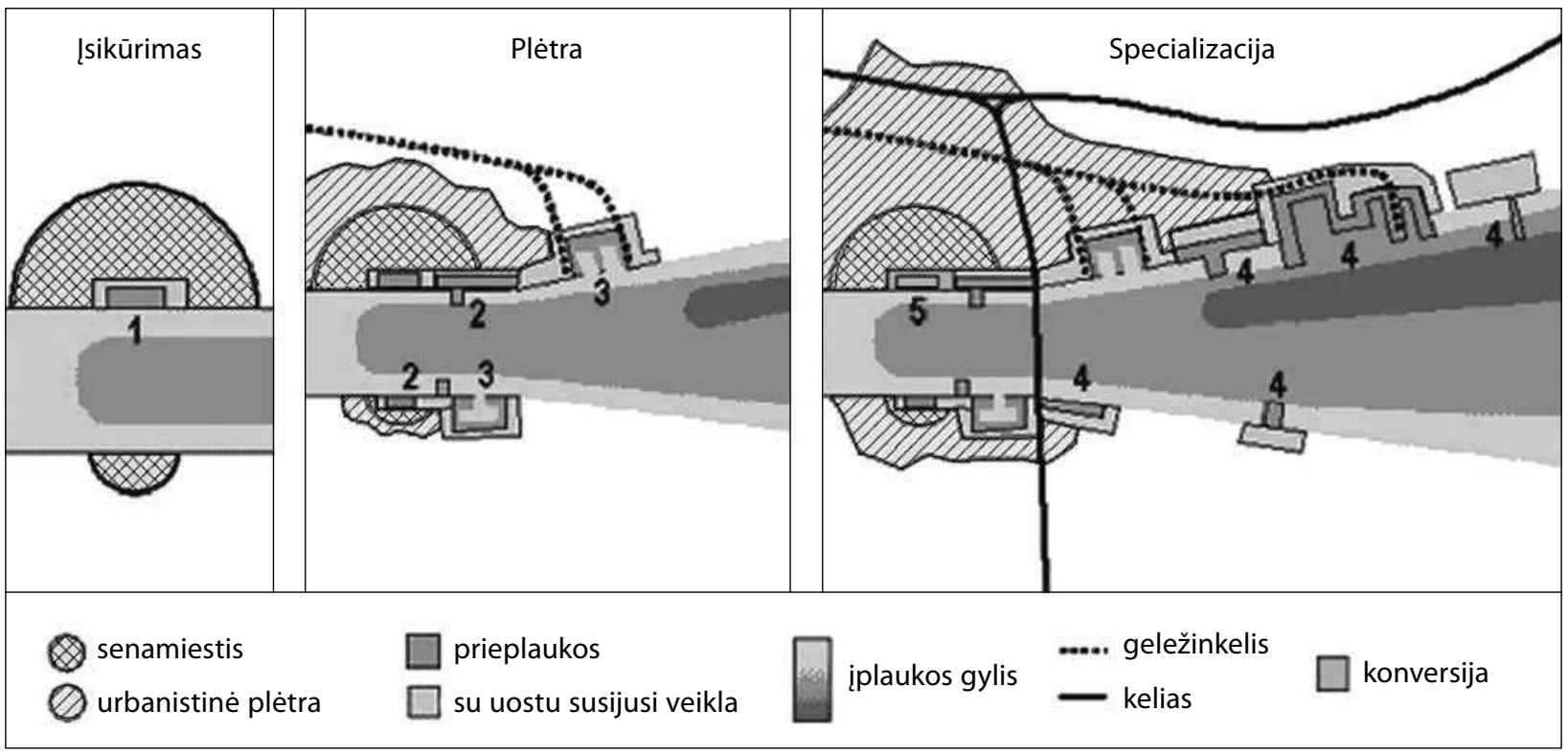

1 pav. Anyport uosto modelis, kuri sukūrè profesorius J. H. Bird'as (1963 m.)

Fig. 1. Anyport model created by Prof J. H. Bird (1963) 
2 lentelè. Baltijos uostamiesčių urbanistinè dinamika

Table 2. Urban dynamics of the Baltic seaports

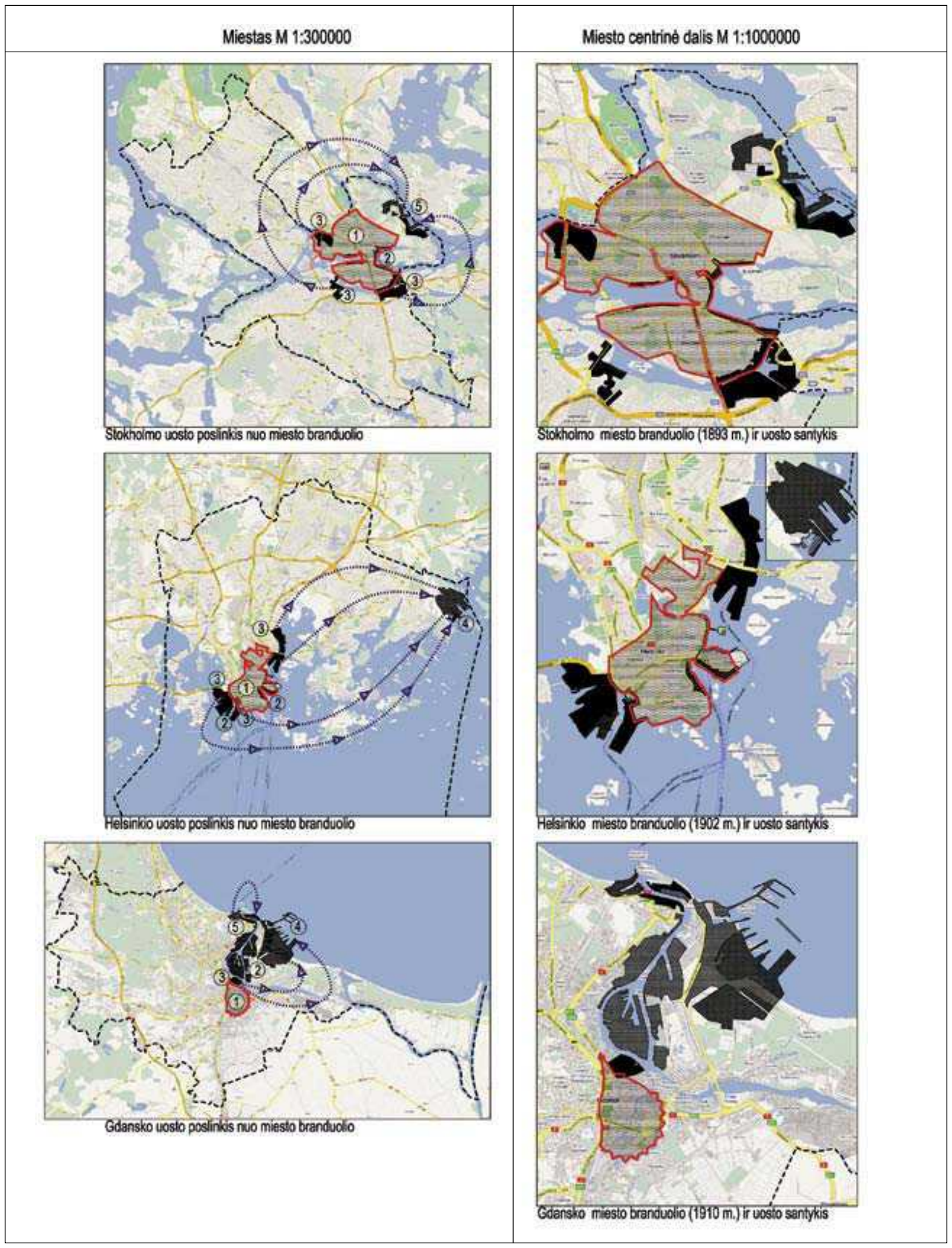


3 lentelè. Baltijos uostamiesčių urbanistinè dinamika (tęsinys)

Table 3. Urban dynamics of the Baltic seaports (continued)

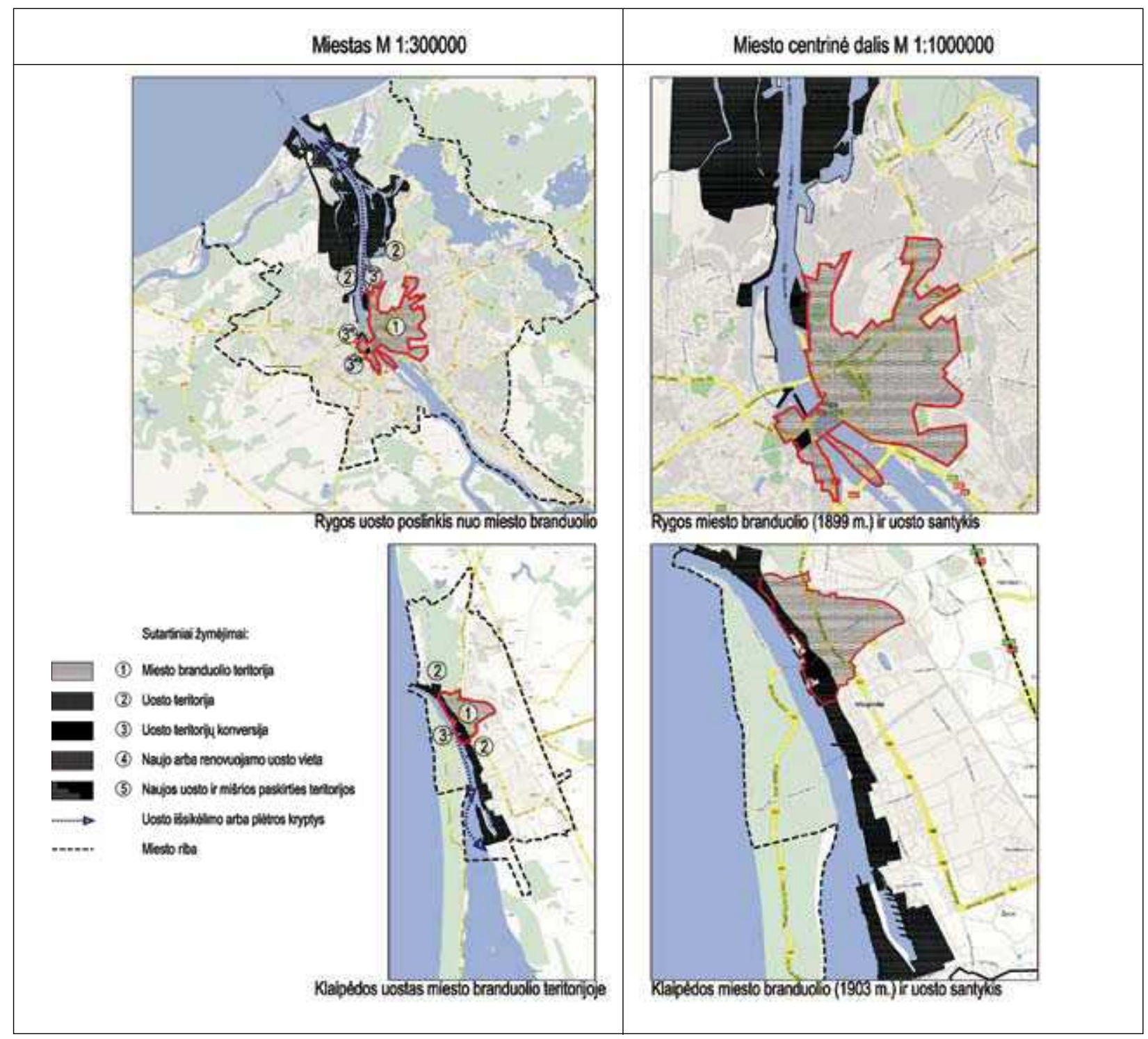

miesto urbanistinị audinị ir skirta keleiviniam transportu. Kitos pakrantès dalys - Lindhagen vakaruose ir Hammarby Sjostadt - užima dali branduolio, tačiau yra jau regeneruojamos arba parengti ju pertvarkymo planai (Antique maps... 2009; The city of Stockholm... 2009; Commision for Architecture... 2008). Helsinkyje uosto teritorijos dar labiau atitolusios nuo istorinio branduolio - čia yra likusi tik nedidelè uosto dalis, skirta keleiviniam transportui. Branduolio teritorijos neužima, bet su juo turi bendrą ribą Šiaurès ir Vakaru uostai. Jų teritorijas numatyta regeneruoti ir pritaikyti miesto poreikiams, išskyrus pietinę Vakarų uosto dalị, kuri naudojama keleiviniam transportu (Antique maps... 2009; City of Helsinki 2009). Gdansko istoriniame branduolyje taip pat nèra likę uosto teritorijų - jos nutolusios link Vyslos žiočiu. Bendrą ribą su centru turi tik senoji laivų statykla, kurios istorija siekia viduramžius. Šią uosto dali taip pat numatyta pertvarkyti ir atiduoti miesto reikmėms (Antique maps... 2009; Official website of Gdansk 2009). Panašus ir Rygos istorinio branduolio santykis su uosto teritorijomis. Jos taip pat nutolusios link Dauguvos upès žiočių. Su centrine miesto dalimi labiausiai susijusi Andrejsala pramoninè uosto zona, kurią numatyta grąžinti miestui (Historical maps 2009; Municipal portal... 2009). 
Klaipedoje pirmaisiais dviem raidos etapais vyko panaši uosto plètra kaip ir nagrinètuose uostamiesčiuose. Miestas kartu su uostu buvo kuriamas prie Danès upès žiočių, jis augo ir buvo plečiamas gilesniu vandenų link. Vis dèlto specializacijos etapas čia prasidèjo uostui dar nespèjus atitolti nuo miesto branduolio. Didelis šio etapo aktyvumas siejamas su politinèmis priežastimis. Sovietmečiu buvo neaktualus keleivinis transportas, todèl didžioji teritorijos dalis buvo skirta sunkiems kroviniams ir juos plukdantiems laivams priimti. Net ir tos pakrantès teritorijos, kurios pagal savo funkciją galejo egzistuoti turèdamos ryšį su miestu, buvo izoliuotos, baiminantis galimo tarybinių piliečių kontakto su užsieniu. Kita vertus, nedideles uosto galimybes judèti tolyn nuo miesto centro lèmé saugotinos gamtinès teritorijos (Übersichts-Plan... 2009; Klaipėdos miesto bendrasis... 2007), įrèminusios uostą tiek šiaurinejje, tiek pietinèje pusèse. Ypač skausminga šiaurinè riba - dèl jos uostas nebegalèjo lengvai perkèlinèti savo teritorijų gilesnių vandenų link, todèl pradejjo plèstis i pietinę dalị ir gilyn ị miestą. Taigi Klaipédoje uosto teritorijos išsidèstė didžiojoje miesto pakrantès dalyje taip atitverdamos miestą nuo vandens. Kartu atsirado plačios apleistos zonos tarp uosto tvoros ir miesto ittakos sferos, nes tokia kaimynystė tarp teritorijų neužtikrino jokio ryšio.

Nagrinejjant tolesnius uostamiesčių urbanistinès dinamikos etapus bei perspektyvas, svarbus tradicinès J. H. Birdo'o koncepcijos palyginimas su šiuolaikiniu uostų gyvavimo ciklu (2 pav. ). Pirmoji baigiasi sąstingiu arba uosto teritorijos apleidimu. Konversijos iniciatorius šiuo atveju dažniausiai būna miestas, nes veiklos vakuumas dažniausiai reiškia dideles apleistas teritorijas, kurios darko miesto urbanistinį audinị. Daugelis Europos uostų maždaug nuo devintojo dešimtmečio savo teritorijas pradejjo renovuoti pagal šiuolaikinę uos- to gyvavimo ciklo koncepciją, kurioje konversija tampa ir uostų interesų sritimi. Priežastys - sunkiau randami sausumos plotai uostų plettrai ir Europos Sąjungos direktyvos, skatinančios jūrų laivybą bei vidaus vandenų transportą. Šiuo atveju vykstanti sisteminè plètra leidžia išspręsti dvi problemas:

1. Skatinama vidinè miesto plètra, pertvarkant uostų teritorijas, kurių efektyvumo neįmanoma padidinti, arba ieškant mišrios plètros galimybių.

2. Skatinama teritorinius resursus tausojanti uosto veikla, išejimo prie jūros funkciją konvertuojant it vandens kelio naudojimo galimybę (Plan the City... 2007).

Uosto ir miesto dialogas labai priklauso nuo uosto valdymo bei nuosavybès tipo. Iš esmès visi valdymo ir nuosavybès deriniai gali būti veiksmingi. Vis dèlto skirtingos kombinacijos lemia skirtingas urbanistinių transformacijų kryptis bei mastą, nes yra susijusios su žemès resursų naudojimo būdais. Galima būtų išskirti šiuos uostamiesčių urbanistinès dinamikos tipus:

1. Uostų kūrimasis naujose teritorijose, atlaisvinant pasenusias ir apleistas teritorijas miesto reikmèms. Taip uostai kuriami dažniausiai tuomet, kai savivaldybè yra uosto akcininke, o uosto ir miesto teritorijos planuojamos kaip sistema.

2. Neefektyvių uosto teritorijų pertvarkymas ir dalies jų pritaikymas miesto reikmėms, kai uosto efektyvumo didinimas darosi neįmanomas. Šis teritorijų pertvarkymas taip pat yra sisteminis. Jis vyksta tais atvejais, kai savivaldybė turi mažesnį uosto akcijų paketą arba kai neįmanoma rasti naujų teritorijų uostui iškelti.

3. Neefektyvių pastatų pertvarkymas arba renovavimas - dinamiško proceso sukūrimas. Tai sisteminio uosto pertvarkymo pradžia. Šis procesas ilgalaikis, nes uosto veiklai iškelti numatomas ilgas $25-30 \mathrm{~m}$.
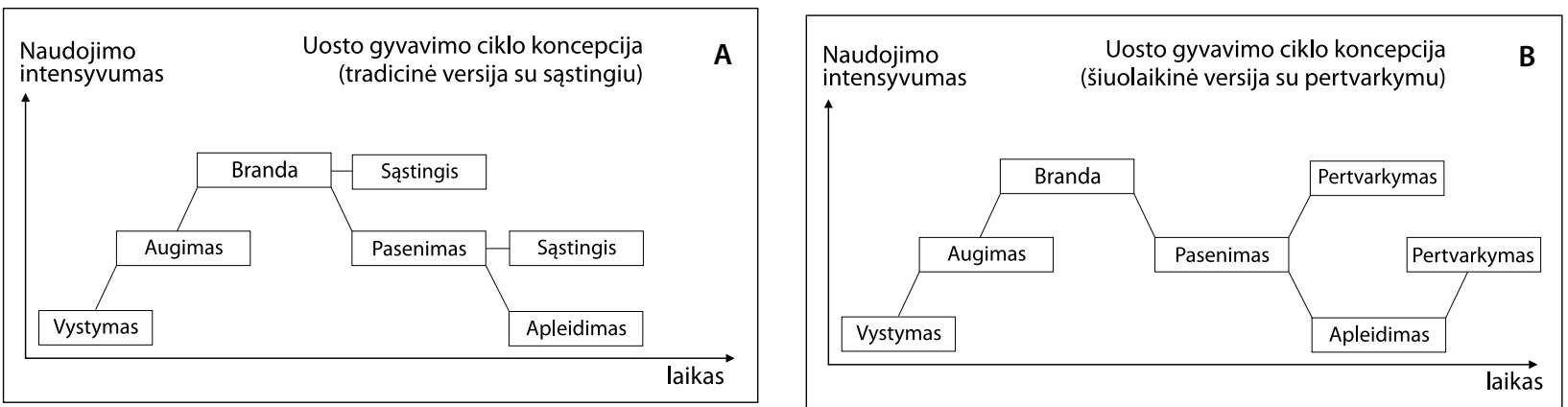

2 pav. Tradicinès $(A)$ ir šiuolaikinès (B) uosto gyvavimo ciklo koncepciju palyginimas

Fig. 2. Seaport life cycle, traditional $(A)$ and contemporary $(B)$ versions 
laikotarpis. Jis gali vykti ir tuomet, kai savivaldybė nèra uosto teritorijų savininkè.

Pirmajam tipui priskiriami Stokholmo ir Helsinkio uostai (2 lentelè, kairè pusè). Stokholmo uostamiesčio plètra ypač didelè, nes vyksta ne vienos savivaldybès, o viso metropolio mastu. Stokholmo urbanistinès dinamikos variklis - trijų uostų plètra. $90 \mathrm{~km}$ ị šiaurę nuo miesto centro suprojektuotas Kapellskar uostas, $80 \mathrm{~km}$ ì pietus - Nynashamn. Uostui išsikèlus ị šias teritorijas, mieste lygiagrečiai regeneruojama ir tankinama 12 rajonų. Trys iš jų buvo susijusios su uosto veikla: Lindhagen - vakaruose, Liljeholmen - pietvakariuose ir didžiausias - Hammarby Sjorstat - pietryčiuose (teritorijos Nr. 3). Trečiasis uostas numatytas paties Stokholmo šiaurineje dalyje, Vartan rajone (teritorija Nr. 5), jis galès priimti krovininius ir kruizinius laivus. Visa projektuojama teritorija bus mišrios paskirties, skirta gyvenamajai statybai, biurams ir prekybai. Tai $3,9 \mathrm{kv} . \mathrm{km}$ plotas, kur uostas ir miestas veikia išvien.

Helsinkyje devintajame dešimtmetyje, vakarų ir šiaurès uostuose pradejjus stigti vietos efektyviai plètrai, savivaldybės sprendimu buvo nuspręsta mažinti uosto veiklą šiose teritorijose ir perkelti ją i naują Vuosari 150 ha uostą, esantį $15 \mathrm{~km}$ ị rytus nuo miesto centro (Nr. 4). Išsikèlus uosto veiklai ị miesto audini integruojamas naujasis pakrantės rajonas Vakarų uoste abipus esamo kanalo bei Kalasatama šiaurinio uosto teritorijoje (teritorijos Nr. 3). Vakarų uoste numatyta palikti tik su keleiviniu transportu susijusią veiklą, svarbiausiu keleiviniu uostu paliekant pietinę jo dalį. Jo dislokacija miesto centre yra didelis privalumas.

Antrajam uostamiesčių urbanistinès dinamikos tipui galima būtų priskirti Gdanską. Čia sẻkmingai uostamiesčio pletrai numatyta uostą ir miestą vystyti vienu metu. Šis būdas yra ịmanomas, nes savivaldybè turi 2 proc. uosto akcijų paketą, kuris ateityje turètų būti padidintas iki 34 proc. Gdanske sistemiškai vystomos trys teritorijos: Naujasis uosto rajonas - istorinè dalis, kur uosto ir miesto veikla organizuojama drauge, bet intensyviau plètojama uosto funkcija (teritorija Nr. 5); Naujasis miesto rajonas, kuriame istorinè laivų statykla pertvarkoma miesto poreikiams (teritorija Nr. 3) ir Stogi rajonas - pagrindiné Gdansko uosto plètros teritorija (teritorija Nr. 4).

Trečiajam tipui atstovauja Ryga. Savivaldybè čia nèra uosto teritorijų savininkè, todèl numatytas ilgas uosto teritoriju atlaisvinimo miesto pletrai laikotarpis. Pagal miesto plètros planą 2006-2018 m. uosto veikla turètų slinktis link Dauguvos žiočių. Kai kurios uosto teritorijos čia yra išsidèsčiusios taip arti istorinio miesto centro, jog krova tapo kliūtimi gyventojams ir kelia pavojų daugiau nei aštuonių šimtų metų senumo pastatams senamiestyje, kuris yra itrauktas $i$ UNESCO pasaulinio paveldo sąrašą. Uosto veikla bus po truputi išstumta iš miesto centro, o čia vystomos naujos multifunkcinès paskirties ir aukštos kokybès urbanistinès teritorijos. Dešiniajame Dauguvos krante nuo Andrejosta iki Kundzinsala turètų būti atlaisvinta 123 ha teritorija. Šių pokyčių katalizatoriais turètų tapti trys miesto reikmèms skirti objektai: dešiniajame Dauguvos krante Rem Koolhas suprojektuotas Šiuolaikinès dailès muziejus (tarptautinio konkurso nugalètojas); kairiajame - Nacionalinès bibliotekos pastatas (architektas Gunnar Birkerts) ir Koncertų salès projektas - architektai Sīlis, Zābers ir Kḷava (projektas - tarptautinio konkurso nugalètojas).

Klaipèdos atveju galètų būti nagrinèjama būtent trečiojo tipo urbanistinès dinamikos galimybè, nes kaip ir Rygoje savivaldybè nèra uosto teritorijų savininkè. Vis dèlto numačius uosto plètros perspektyvas, pakranteje būtų galima ieškoti nedidelių teritorijų pavieniams aukštos architektūrinès kokybės objektams, kurie ateityje galètų tapti aktualių pakrantės dalių konversijos katalizatoriais.

\section{Baltijos uostamiesčių urbanistinès raidos kryptys}

Uostamiesčių urbanistinès raidos dinamika priklauso nuo naujiems uostams reikalingų teritorinių resursų išteklių ir jų išsidèstymo mieste. Pagal šių resursų naudojimo galimybes analizuojami tokie uostų plètros modeliai: 1) žaliųjų plotų, 3) rudųjų plotų 2) mèlynųjų plotu (Plan the City... 2007).

Žalieji plotai - laisvos, nenaudojamos, kartais gali būti žemès ūkio paskirties teritorijos.

Rudieji plotai - apleistos, nenaudojamos pramoninès ar komercinés paskirties teritorijos, kurių gruntas gali būti užterštas ir kuriose galima konversija.

Mèlynieji plotai - vandenyje pilamos dirbtinès salos uostų plètrai.

Baltijos uostų atveju plètra vien žaliuosiuose plotuose sunkiai įmanoma, nes tokių teritorijų arba nėra, arba jose galioja įvairūs aplinkosauginiai apribojimai. Dar viena priežastis - darniosios plètros reikalavimai, ribojantys miestų augimą. Uostų plètrai vis dažniau taikomi mèlynųjų ir rudųjų plotų modeliai bei ịvairūs mišrūs variantai. Nagrinètuose uostamiesčiuose taikyti tokie uostų plètros modeliai: Stokholme Nynashamn uosto plètrai taikytas mišrus žaliųjų ir mėlynųjų plotų modelis, Kapellsakar - rudųjų plotų, Vartan - mišrus 
rudųjų ir mèlynųjų; Helsinkyje iš esmès taikytas rudųjų plotų modelis, tik ryšiams su naujuoju Vuosari uostu žalieji plotai; Gdansko uosto plètrai taikomas rudųjų ir mèlynųjų plotų modelis; Rygoje kol kas planuojamas rudųjų plotų modelis, aktyvinant funkcijas esamose teritorijose arčiau upès žiočių. Apibendrinant galima būtų pasakyti, kad populiariausias - rudųjų plotų modelis, o didinant pakrantès perimetrą papildomai taikomas mèlynųjų plotų modelis. Išimtis - Nynashamn uosto dalis, kur uostas plečiamas ị nenaudojamas teritorijas. Vis dèlto ši teritorija turi ryši su senąja uosto dalimi, be to, jame numatyta mišri funkcija, taip pat diegiamos moderniausios technologijos, kurios šiam uostui turètų suteikti paties ekologiškiausio Europos uosto statusą.

Uostų plètroje labai svarbu, kad procesas nepasidarytų svarbesnis nei forma (Daamen 2007). Tarptautinè miestų ir uostų asociacija (AIVP) $2007 \mathrm{~m}$. perengtoje mokslinèje studijoje „Miesto su uostu planavimas“ kaip svarbiausią uostų plètros aspektą išskiria ryšių tarp uosto ir miesto stiprinimą, todèl siūlo tokias urbanistinès raidos kryptis (Plan the City... 2007):

1. Uosto ir miesto susiejimas. Tai patekimo i uosto teritorijas bei i tarpines uosto-miesto teritorijas gerinimas tiek pėsčiomis, tiek visomis kitomis transporto rūšimis; uosto teritorijų efektyvumo verifikavimas bei naujų scenarijų kūrimas, rūpinantis ryšiais su miestu; naujų ryšių kūrimas, ieškant naujų, efektyvių teritorijos panaudojimo būdų, didinant uosto konkurencingumą; senų ryšių, kurie dalį teritorijų sujungia, izoliuodami kitas, pertvarkymas.

2. Urbanistinio matmens integravimas į uosto teritorijas. Tai siūlymas uostą tvarkyti kaip urbanistinę erdvę, rūpintis visų čia statomų pastatų (tarp jų ir sandèlių) architektūrine kokybe, padaryti uostą matomą ir vizualiai patrauklų. Šioje gairèje siūloma artinti miestą prie uosto, išsidèsčiusio ant vandens, bei rasti būdų bendrai naudotis vandeniu.

3. Naujų funkcijų integravimas uosto teritorijose. Tai visų įmanomų techninių sprendimų naudojimas ir naujų paieška, siekiant mišrių funkcijų galimybių. Siūloma: ieškoti galimybių sukurti ryši tarp pramoninio uosto ir miesto, struktūrizuojant ir klasifikuojant uosto veiklą; suteikti prioritetų mišriems keleiviniams terminalams ir susieti juos su miestu komercine bei visuomenine funkcijomis; lanksčiai naudoti rezervines teritorijas ir buferines zonas, inicijuojant jose pokyčius kultūrinèmis funkcijomis, instaliacijomis, moduliniais, lengvai išardomais pastatais.
4. Visuomenès rengimas pokyčiams pakrantėse bei jos integravimas į uosto gyvenimą. Tai mokslininkų ir akademinès visuomenès bendradarbiavimas ieškant naujų pakrantės naudojimo būdų; uosto ir kraštovaizdžio kaip svarbių miesto simbolių stiprinimas; uosto atvèrimas bei modernių veiklos būdų pristatymas visuomenei.

\section{Siūlomos Klaipėdos urbanistinès raidos kryptys}

Palyginti neseniai susiformavusi rinkos ekonomika, nebaigta žemės reforma, susiformavusi miesto antropogeninè aplinka, ekonominès galimybès, socialinis poreikis, aplinkos kokybè ir gyvenimo būdas Lietuvos miestuose formuoja unikalius problemų rinkinius (Juškevičius, Valeika 2007). Knygoje „Lietuvos miestų sistemų raida. Vilnius“ autoriai kaip svarbiausią šių rinkinių sudedamąją dalị ịvardija sisteminio planavimo nebuvimą. Taigi Klaipèdos uosto ir miesto kaitos veiksniai taip pat nesiejami ị sistemą, todèl daugelis potencialiai tvarkytinų teritorijų taip ir lieka tikètinos.

Ieškant perspektyviausių Klaipėdos uostamiesčio urbanistinès plėtros krypčių, svarbu dar kartą žvilgterèti ị pakrančių naudojimo efektyvumo tyrimą. Pagrindinès kompanijos, vykdančios krovos darbus ir perkraunančios daugiau kaip 90 proc. krovinių Klaipèdos uoste, yra: „Klaipedos nafta“, „Klaipėdos jūrų krovinių kompanija“ (KLASCO), „Bega“, „Klaipedos Smelte“ ir „Klaipedos terminalo grupe““. Šios įmonès užima tik 29 proc. visos 623 ha teritorijos ir 38 proc. (iš $27022 \mathrm{~m}$ ) bendro krantinių ilgio. Likusią 71 proc. uosto dalį užima aptarnaujančios tarnybos, keltų ir jų prieigų teritorijos, kruizinių laivų terminalai, laivų remonto dirbtuvès ir kitos krovos kompanijos. Dalis šios veiklos būtina, kad būtų užtikrintos uosto funkcijos. Vis dèlto didžiąją dalį užima krovos kompanijos, todèl akivaizdu, kad teritorija naudojama neefektyviai, o užimami plotai visiškai neadekvatūs veiklos užmojams (3 pav.).

Pelningiausiai dirbančių įmonių išsidèstymas pakrantèje nesusijęs su uosto gyvavimo ciklu - šiaurinejje dalyje, kur gyliai didžiausi, uosto aktyvumas tèra vidutinis, o plotai pietinèje dalyje plačiai išsidriekę į miesto pusę (4 pav.). Taip yra todèl, kad prieplaukos ir ịrenginiai seniai pasenę, sandèliai nepritaikyti šiuolaikinei logistikai, tam tikra veikla, pavyzdžiui, mašinų detalių gamyba - tiesiog sovietinès pramonès palikimas.

Klaipėdoje neefektyviai naudojamų teritorijų renovacijos procesas yra atsilikęs maždaug dvidešimčia 
metų, nes vyksta neplanuotai ir inertiškai. Pavyzdys „Laivitès" teritorijoje $2005 \mathrm{~m}$. rekonstruotos krantinès, o $2006 \mathrm{~m}$. birželio $28 \mathrm{~d}$. Uosto direkcija jau pasirašé šio sklypo nuomos sutartį su UAB „Memelio miestas“, kuri teritojoje statys gyvenamuosius ir komercinès paskirties pastatus.

Klaipedos atveju, darant prielaidą, kad uostas turètų judèti link gilesnių vandenų - ịplaukos ị Kuršių marias - akivaizdu, kad neįmanoma pasinaudoti ža-

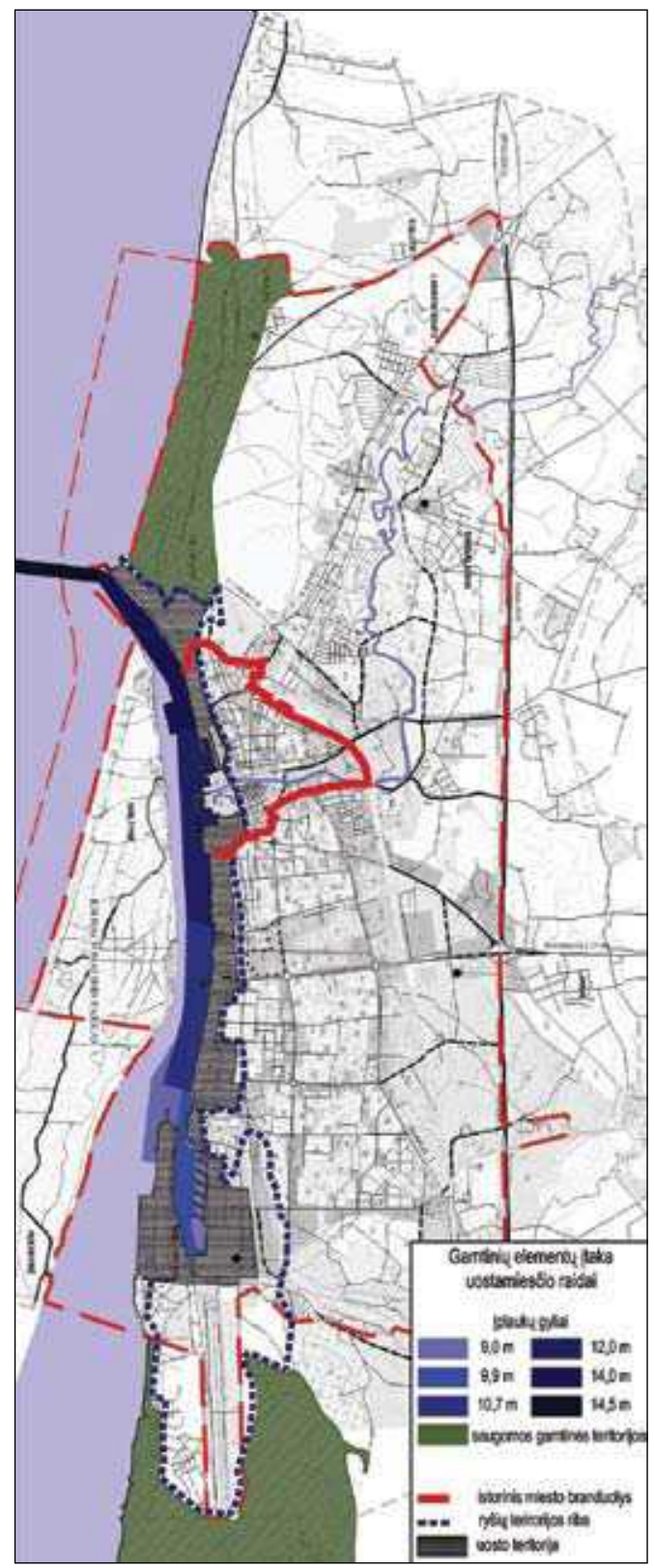

3 pav. Gamtinių elementų ịtaka uostamiesčio urbanistinei raidai

Fig. 3. Impact of natural elements on urban development of the seaport liųjų plotų modeliu, nes gretimos teritorijos yra vertingos ir saugomos kaip gamtinès (4 pav.). Taigi aktualūs būtų rudųjų ir mèlynųjų plotų modeliai. Nagrinejjant rudųjų plotų modelį, Klaipèdos uosto pietinę dalị vertètų perkvalifikuoti, ateityje numatant laivybą, kuriai užtektų čia esančių gylių ir mažesnių sausumos plotų. Tai tinkamas būdas miestui priartèti prie vandens. Didžiausias uosto vystymo potencialas yra šiaurinèje dalyje, todèl būtini aktyvesni krantinių tvarkymo

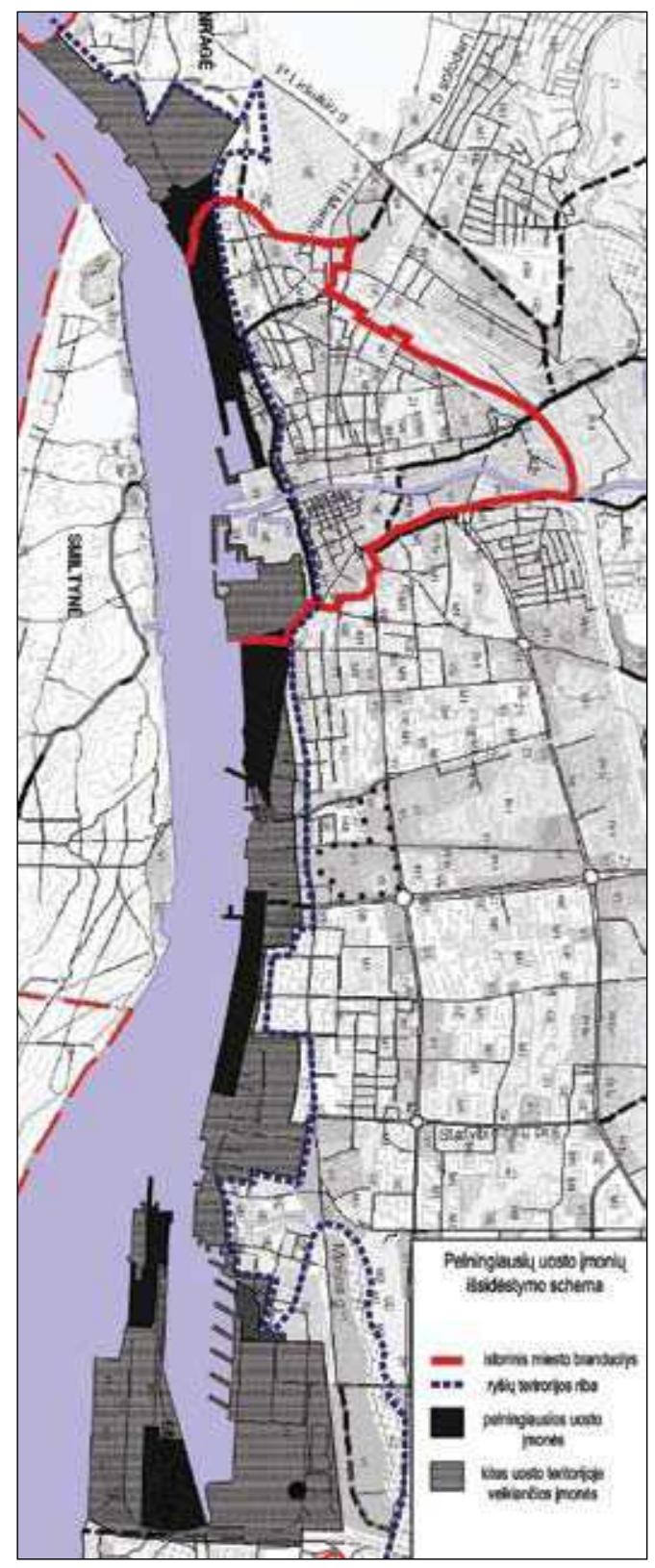

4 pav. Pelningiausių uosto įmonių išsidèstymo schema

Fig. 4. Distribution scheme of the most efficient enterprises of the seaport 
darbai ir intensyvesnis sausumos susisiekimas su uosto teritorijomis. Ieškant „mèlynosios“ plètros galimybių, be abejo, svarbus giliavandenio uosto projektas. Prie íplaukos ị Kuršių marias numatyta sala turètų tenkinti ne vieno operatoriaus interesus, o būti gerokai didesnè ir integruoti daugiau uosto funkcijų.

Esminis bet kokių būsimų Klaipèdos urbanistinių pertvarkymų aspektas - sisteminè plètra, nes iki šiol uostas ir miestas yra atskiri organizmai, o ne tarpusavyje integruotos uostamiesčio dalys. Sisteminè plètra padès sèkmingiau panaudoti uosto ir miesto plètrai skiriamas lešas, leis efektyviau naudoti pakrančių bei uosto-miesto ryšiu teritorijas, užtikrins geresnę meninę-urbanistinę uostamiesčio kokybę. Ši plètra turètų vykti stiprinant ryšius tarp uosto bei miesto ir remtis anksčiau aptartais būdais:

1. Uosto ir miesto susiejimo galimybę būtų galima realizuoti silpninant uosto urbanistinę ribą: Pamario-N. Uosto-Pilies-Minijos trasos dalį-N. Uosto gatvę - reikètų „paslèpti“ po žeme, taip pat organizuoti pėsčiujų traukos centrus pakranteje (Morkūnas 2006).

2. Rūpinantis urbanistinio matmens integravimu i uosto teritorijas, Klaipédoje pirmiausia reiktų spręsti Piliavietès ir Mažosios Vitès (Memelio miesto) urbanistines problemas, kuriant viešąsias erdves bei aukštą architektūrinę kokybę. Sandèliai ir kiti pramoninès ar administracinès paskirties objektai uosto teritorijoje taip pat turètų būti statomi, rūpinantis jų santykiu su miestu, todèl vertètų rengti ne atskirus uosto ir miesto plètros planus, o bandyti juos susieti. Akivaizdus neigiamas pavyzdys - rengiamas „Begos“ detalusis planas, neatitinkantis specialaus Klaipedos aukštybinių pastatų išdèstymo plano. Taip pat būtų svarbios vizualinio atvirumo paieškos uosto teritorijose ties Naujosios Smiltynès perkèla bei Klaipėdos keleivių ir krovinių terminalu. Urbanistinio matmens integravimą reiktu organizuoti geriau išnaudojant vandens teikiamą potencialą - stiprinant skersinius pėsčiųjų ryšius su mariomis, ieškant viešųjų erdvių galimybių pakrantèje: ties Melnrage, tvarkant Pamario gatvès aši; ties „Baltijos laivų statykla“ - Bijūnų gatvès ašį; tarp Naujosios Smiltynès perkèlos ir Klaipèdos krovinių terminalo - Agluonos-Varnènų gatvès aší; ties LISCO keleivių terminalu - Senosios Smiltelès gatvès ašį (Morkūnas 2006).

3. Urbanistinio matmens integravimas labai susijęs su naujų funkcijų organizavimu ir jų susipynimu pakrantèje. Naujų funkcijų galimybes vertètų na- grinèti konteinerių terminalų ir žvejybos uosto teritorijose, kur nedidelè taršos grèsmè. Šiose zonose, pasibaigus darbo valandoms, galètų veikti kavinès, kino teatrai ar kiti visuomeninès paskirties objektai. Funkcijų integravimo požiūriu Klaipèdos uoste labai aktualus ir rezervinių bei buferinių zonų naudojimas. Tai didžiulès, beveik prie vandens esančios teritorijos: ties „Klaipedos Smelte“ ir Naująja Smiltynès perkèla, atkarpa tarp Naujosios Uosto gatvès ir KLASCO bei „Klaipedos Naftos“ rezervinè teritorija prie uosto vartų. Dabar tai negyvos zonos. Kai kurios iš jų galbūt tikrai bus reikalingos uostui ateityje, tačiau šiuo metu čia būtų galima inicijuoti tam tikrus pokyčius - organizuoti laikino naudojimo funkcijas. Pavyzdžiui, statyti modulinius, lengvai surenkamus pastatus, kurti viešąsias erdves su meninemis instaliacijomis, organizuoti kitą kultūrinę veiklą.

4. Sprendžiant Klaipedos uostamiesčio urbanistinės raidos klausimus, visuomenè turètų būti įtraukiama rengiant galimybių studijas, jas viešai pristatant bei aptarinëjant. Galimybių studijų rengimą galètų bendrai inicijuoti miesto ir uosto valdžia, o vykdyti - Lietuvos mokslo institucijos.

\section{Išvados}

1. Globalizacija suaktyvino daugybę pasaulyje vykstančiu procesų, tarp jų - ekonominius bei technologinius, taip pat tapo naujų urbanistinių principų atsiradimo prielaida. Šie veiksniai skatina kiekybinę plètrą tapti kokybine, iš naujo įvertinti pakrančių naudojimo efektyvumą ir ieškoti teritorinių rezervų. Procesas ypač aktyvus labiausiai globalizacijos paveiktose Baltijos pakrantėse. Čia, daugelyje uostamiesčių, jis tapo didžiulio uosto ir miesto teritoriju persiskirstymo priežastimi.

2. Vanduo - jūra, upé, ežeras - visuotinai svarbus resursas, kuris gretimoms teritorijoms suteikia pridètinès vertės, tačiau pats savaime joms negarantuoja meninès aplinkos vaidmens. Efektyviam pakrančių naudojimui, užtikrinančiam funkcijų intensyvumą bei meninę-urbanistinę kokybę, būtinas sisteminis planavimas, nes kitaip menkai naudojamos uostų teritorijos taip ir lieka tikètinos, o ne integruotos - panašiai kaip funkcinio zonavimo principu suplanuoti teritoriniai rezervai.

3. Baltijos uostamiesčių urbanistinės raidos dėsningumus lemia vidinis uostu poreikis keistis ir išorinis miesto spaudimas aktyviai naudoti pakrančių teritorijas. Šiuos veiksnius siejant $i$ sistemas galima: iš naujo 
verifikuoti potencialą, kurị uostų teritorijos praranda arba igyja, keičiantis ekonominems sąlygoms ir technologijoms; numatyti teritorijų vystymo programas, ipareigojant teritorijų vystytojus spręsti meninès-urbanistinès kokybès klausimus; numatyti teritorijose funkcijų i̇vairovę ir viešąsias erdves, keliant aukštus reikalavimus architektūrinei kokybei. Tokiuose uostamiesčiuose kaip Klaipeda uosto ir miesto kaitos veiksniai nesiejami ị sistemą, todèl daugelis potencialiai tvarkytinų teritorijų taip ir lieka tikètinos.

4. Globalizacijos sąlygomis Baltijos uostamiesčiams kyla panašūs iššūkiai, o ekonominiai bei technologiniai procesai stimuliuoja urbanistinę raidą, tačiau skirtingos politinès, socialinès bei gamtinès aplinkybès lemia skirtingus urbanistinių transformacijų rezultatus ir mastą. Aktyviausi uostamiesčių urbanistinès dinamikos procesai vyksta tose pakrantèse, kuriose miestas turi daugiausia galimybių realizuoti savo interesus, ypač metropoliuose. Vis dèlto net ir tais atvejais, kai savivaldybė nèra uosto teritorijų savininkè, sisteminis planavimas leidžia smulkesnio masto, bet aukštos architektūrinès kokybès objektais inicijuoti didesnius pokyčius.

5. Plètra ruduosiuose ir mèlynuosiuose plotuose - dažniausiai taikomas Baltijos uostamiesčių urbanistinio vystymo modelis, nes jam igyvendinti nereikalingos naujos teritorijos, o stengiamasi racionaliai panaudoti esamus resursus. Klaipedos uostamiesčiui taip pat galètų būti aktualus toks rudųjų ir mèlynụjų plotų plètros modelis, nes ne tik Klaipédoje, bet ir visame Lietuvai priklausančiame pajūrio ruože nèra jokių laisvų teritorijų uosto plètrai.

6. Bet kurio uosto raida nèra baigtinis procesas, todèl esminè uostamiesčių planavimo nuostata turètų būti ryšio tarp uosto ir miesto stiprinimas, naudojantis ekonominiu bei technologiniu procesu teikiamomis galimybėmis. Ši nuostata realizuojama siejant uosto ir miesto teritorijas keliais bei pèsčiujų takais, integruojant ị uostų struktūras urbanistinị matmenị, ieškant mišrių funkcijų taikymo galimybių bei ị pakrančiu urbanistinio vystymo procesą itraukiant visuomenę. Klaipedos pakrantes taip pat reikètų tvarkyti rūpinantis uosto ir miesto ryšiais, nes tik taip galima užtikrinti efektyvų jų naudojimą tiek uosto, tiek miesto labui.

\section{Literatūra}

Antique Maps of Scandinavia \& Nordic Countries. 2009 [interaktyvus] [žiūrèta 2009-01-07]. Prieiga per internetą: $<$ http://www.vintage-views.com/eshop/home. php?cat $=539>$.
Baltic Ports Organization. 2009 [interaktyvus] [žiūrèta 200903-12]. Prieiga per internetą: $<$ http://www.bpoports. $\mathrm{com} />$.

Bird, J. H. 1963. The Major Seaports of the United Kingdom. London: Hutchinson. 454 p.

Carley, M.; Ferrari, S. G.; Thiam, S.; Smith, H. 2007. The cool sea. Waterfront communities project toolkit [interaktyvus] [žiūrèta 2009-02-15]. Prieiga per internetą: <http://www. waterfrontcommunitiesproject.org/toolkit.html>.

City of Helsinki. 2009 [interaktyvus] [žiūrèta 2009-02-15]. Prieiga per internetą: <http://www.hel.fi/wps/portal/ Helsinki_en?WCM_GLOBAL_CONTEXT=/Helsinki/en/ Etusivu>.

Commission for Architecture and the Built Environment. Case studies. 2008 [interaktyvus]. Hammarby Sjostad, Stockholm [žiūrèta 2008-12-15]. Prieiga per internetą: $<$ http://www.cabe.org.uk/case-studies/hammarbysjostad?photos=true\&viewing $=774>$.

Daamen, T. 2007. Sustainable Development of the European Port-City Interface. Sustainable Urban Areas [interaktyvus]. Rotterdam, 25-28 June. 21 p. [žiūrèta 2008-12-15]. Prieiga per internetą: $<$ http://www.enhr2007rotterdam. nl/documents/W19_paper_Daamen.pdf $>$.

European Seaports Organisation. 2009 [interaktyvus] [žiūrèta 2009-03-12]. Prieiga per internetą: <http://www.espo.be/ Home.aspx>.

Eurostat. European Statistics [interaktyvus] [žiūrèta 2009-02-20]. Prieiga per internetą: <http://epp.eurostat. ec.europa.eu/portal/page/portal/eurostat/home/>.

Freeport of Riga. 2009 [interaktyvus] [žiūrèta 2009-02-15]. Prieiga per internetą: <http://www.freeportofriga.lv/ eng/>.

Friedman, T. L. 2005. Lexus ir alyvmedis. Vilnius: Vaga. 591 p.

Historical maps. 2009 [interaktyvus] [žiūrèta 2009-01-07]. Prieiga per internetą: $<$ http://www.discusmedia.com/catalog.php?id=24961\&profile $=$ map $>$.

International Association of Cities and Ports. News AIVP. Projects. 2009 [interaktyvus] [žiūrèta 2009-03-10]. Prieiga per internetą: $<$ http://www.aivp.org/projets_6.html>.

Juškevičius, P.; Jauneikaitė, K. 2008. Urbanistinių struktūrų formavimo ir žemès naudojimo klasifikavimo problematika, Urbanistika ir architektūra 32(4): 240-247. doi:10.3846/1392-1630.2008.32.240-247

Juškevičius, P.; Valeika, V. 2007. Lietuvos miestų sistemų raida. Vilnius: Baltijos kopija. 240 p.

Juškevičius, P.; Valeika, V.; Burinskienè, M.; Paliulis, G. 2006. Lietuvos miestu susisiekimo sistemos. Klaipèda. Vilnius: Technika. $181 \mathrm{p}$.

Klaipédos miesto bendrasis planas. Patvirtintas 2007-04-05 Klaipèdos savivaldybès [interaktyvus]. Rengejjas UAB „Miestprojektas“ [žiūrèta 2008-12-15]. Prieiga per internetą: <http://www.klaipeda.lt/stotisFiles/uploadedAttachments/KL_2000020083931559.jpg >.

Klaipédos valstybinis jūrų uostas [interaktyvus] [žiūrèta 2009-02-15]. Prieiga per internetą: $<$ http://www.portofklaipeda.lt/lt.php>. 
Morkūnas, E. 2006. Klaipédos miesto pramonès teritoriju prie Kuršiu mariu urbanistinè koncepcija: baigiamasis magistro darbas (VGTU, Architektūros fakultetas, Urbanistikos katedra, vadovè I. Alistratovaitè).

Municipal Portal of Riga [interaktyvus] [žiūrèta 2009-02-15]. Prieiga per internetą: <http://www.riga.lv/EN/Channels/ About_Riga/default.htm>.

Official webside of Gdansk [interaktyvus] [žiūrèta 2009-02-15]. Prieiga per internetą: <http://www. en.gdansk.gda.pl/>.

Plan the City with the Port. Regional Framework Operation Hanse Passage, Regional Development Fund INTERREG IIIC, West Zone. 2007 November [interaktyvus]. La Havre. 136 p. [žiūrèta 2008-11-10]. Prieiga per internetą: <http:// www.freeportofriga.lv/PROJEKTI/Guide_PCP_2007_ EN.pdf>.

Port of Gdansk [interaktyvus] [žiūrèta 2009-02-15]. Prieiga per internetą: <http://www.portgdansk.pl/en>.

Port of Helsinki [interaktyvus] [žiūrèta 2009-02-15]. Prieiga per internetą: <http://www.portofhelsinki.fi/english/>.

Ports of Stockholm [interaktyvus] [žiūrèta 2009-02-15]. Prieiga per internetą: <http://www.portsofstockholm.com/>.

Remesar, A. 2005 Introduction from Promenades to Waterfronts. Art for Social Facilitation [interaktyvus] [žiūrèta 2008-12-15]. Prieiga per internetą: <http://www. ub.es/escult/epolis/artfsoc/artforsocial_index.pdf $>$.

The City of Stockholm [interaktyvus] [žiūrèta 2009-02-16]. Prieiga per internetą: <http://stockholm.se/-/English/>.

Übersichts-Plan der Stadt Memel [interaktyvus] [žiūrèta 200902-15]. Prieiga per internetą: <http://www.bork-on-line. de/Memel/lt-index.htm>.

Uosto valdymas ir politika: iššükiai, keliai, sprendimai. 2005 gruodis. Lietuvos laisvosios rinkos instituto studija [interaktyvus] [žiūrèta 2009-03-12]. Prieiga per internetą: <http://www.lrinka.lt/index.php/analitiniai_darbai/ llri_studija_uosto_valdymas_ir_politika_issukiai_keliai_sprendimai/2279>.

\section{URBAN STRUCTURE DYNAMICS OF KLAIPĖDA AND THE OTHER BALTIC SEAPORTS IN THE CONTEXT OF GLOBALIZATION}

\section{E. Truskauskienė}

Abstract. The paper presents a part of the dissertation work "Urban dynamics of the Lithuanian seaside". This section covers the problems of Klaipeda urban development and assessment of new opportunities under the effect of globalization factors. Klaipeda is compared with the other Baltic seaports in order to investigate its potential for redevelopment and dynamics of the urban structure.

The study reveals the most important trend of urban dynamics in the era of globalization - an integrated development of the seaport and city system. Common development of these structures allows to solve the problems of both port and city in the most efficient way. In such a context Klaipeda appears as a seaport city which is changing along the seaside contrary to the natural seaport life cycle. This contradiction occurs because of urban development which is complicated by natural factors, land shortage and difficulties in coordinating different interests of stakeholders. Klaipèda seaport could also be applicable for rational decision-making in the field of urban development. It could be implemented by applying the pratice of the other Baltic seaports which is based on analysing the seaside efficiency, using new seaport development models and trends of systematic urban planning. On this basis Klaipeda should become an area of urban development with an integrated planning of the seaport and city system considering the relationship between these still little related parts.

Keywords: urban dynamics, globalization, systematic development, seaport life cycle, development in green, brown and blue areas, integration.

\section{EGLE் TRUSKAUSKIENE்}

Master, doctoral student (2005), Dept of Urban Design, Vilnius Gediminas Technical University (VGTU), Pylimo g. 26/Traku g. 1, LT-01132 Vilnius, Lithuania.E-mail: etruske@gmail.com

Master of Architecture, VGTU, 2000. Research interests: urban planning, urban development strategies in the Baltic seaport cities. 